\title{
Empowerment of Refugees by Language: Can ESL Learners Affect the Target Culture?
}

\author{
Fereshteh Tadayon and Ali Khodi
}

Numerous studies have investigated the changing patterns of immigration, the growth of multicultural-multilingual societies, and the important role of language in identity construction. Unfortunately, the issue of identity construction is affected by a variety of factors such as language learning and acquisition underlying different contexts and cultures, whereas, to some extent, the effects of language attrition and acculturation on the target community have not received the necessary attention. This crisis is defined primarily as the changes that occur in societies as the result of the amalgamation of languages for communication. It has been clearly stated by Kramsch (2008) that language has the potential to affect speakers' minds and identities. Moreover, immigrants' liberatory autonomy can empower them to be critical thinkers in new societies (Allwright $\mathcal{E}$ Hanks, 2009). This raises the question of how to preserve the distinguishing features of societies from potential cultural and social changes brought about by the people who use languages other than the national language of a country. Further elaboration on the effects of language in empowering immigrants is highly recommended. In this article, given the importance of patterns of immigration underlying second language acquisition and English mainstream education, we discuss the diminishing cultural and linguistic traces of non-English-speaking immigrants as a result of the encouraged loss of their first languages.

De nombreuses études se sont penchées sur les tendances changeantes de l'immigration, la croissance des sociétés plurilingues et le rôle important de la langue dans la construction identitaire. Malheureusement, alors que la question de la construction identitaire est affectée par divers facteurs tels l'apprentissage et l'acquisition d'une langue dans différents contextes et différentes cultures, les effets de l'érosion des langues et l'acculturation de la communauté cible n'ont pas reçu toute l'attention voulue. Cette crise se définit principalement par les changements qui ont lieu dans les sociétés en raison de l'amalgamation des langues pour la communication. Kramsch (2008) a affirmé clairement que la langue a le potentiel d'affecter l'esprit et l'identité des locuteurs. De plus, l'autonomie libératoire des immigrants peut les habiliter à penser de manière critique dans les nouvelles sociétés (Hanks \& Allwright, 2009). Cela soulève la question à savoir comment préserver les traits distinctifs des sociétés des changements culturels et sociales qui pourraient découler des actions de personnes qui parlent des langues autres que la langue nationale d'un pays. Nous recommandons fortement de poursuivre l'étude des effets du langage sur la responsabilisation des immigrants. Compte tenu de l'importance des tendances de l'immigration sous-jacentes à l'acquisition 
d'une langue seconde et à l'éducation régulière en anglais, nous discutons de la diminution des traces culturelles et linguistiques des immigrants allophones découlant du manque d'encouragement à préserver leur première langue.

KEYWORDS: English as an additional language, empowerment, social justice, refugees

\section{Multilingual, Bilingual and Multicultural Policies Underlying Immigration}

Issues related to patterns of immigration underlying second language acquisition (SLA) have led to demographic changes in English-speaking countries such as the United Kingdom, Canada, the United States, and Australia (Ashworth, 2000). With the growth of immigration to Canada, multilingualism, as well as multiculturalism (diversity) and human rights (equity), have been debated in recent decades. Moreover, learning English as an international language has gained a greater importance, enabling immigrants to develop and attain empowerment in different social, historical, and cultural contexts. However, there is a paradox in the Canadian equity and diversity agenda in ESL education programs in terms of theory and practice.

On one hand, English mainstream education achieves cultural and linguistic assimilation for non-English speakers by fostering the loss of first languages and cultures of people with different social and economic status. Alternatively, Canadian policy provides equitable conditions for speakers to choose one of its official languages (i.e., English or French). Therefore, in spite of the fact that Canadian multicultural policies emphasize the provision of equality rights through preserving cultural retention rights and safeguarding individual choice in language community participation, people avail themselves of multicultural policies as a matter of individual choice.

The need for communication, which is paramount for success, encourages people to use English extensively, especially in multilingual societies. In terms of Canadian policies concerning multilingualism and multiculturalism, Magsino (1995) recognized four aspects: (a) cultural retention, (b) cultural sharing, (c) equality of opportunity, and (d) individual freedom. In this sense, Canadian multiculturalism makes an effort to strengthen consolidating Canadian identity and social values by using one of the two official languages and preserving native languages and human rights with regard to common ethics and values. With reference to human rights, all speakers are entrusted with the right to benefit from the equitable opportunities in Canadian society through the elimination of cultural and language barriers that may stem from their incompetency in communication. Besides, Canadian multicultural policies venerate individuals' freedom of choice in cultural and language community participation through provision of bilingual or dual-language programs 
called Language Instruction for Newcomers to Canada (LINC) and aim to enable newcomers to achieve their educational or career goals.

\section{ESL Education Programs and Social Identity}

To facilitate the acquisition of an official language by new immigrants, refugees, and international students, ESL curricula have introduced various programs, such as the Canadian Employment and Immigration Commission and English as a second language (ESL) programs "to ease the New Canadian's transition into Canadian society" (Avalon Community College, 1984, p. 1, as cited in Bassler, 1990, p. 104).

The aim of these programs is to assist ESL learners to gain expertise in a wide variety of English and literacy skills comprising speaking, listening, writing, and reading for living and working in the Canadian context. Surprisingly, they can also bring about multilingual/intercultural outcomes or subtractive assimilation in students. These programs, with the aim of language learning enhancement in immigrants, inexorably influence their identities, which are not static qualities of an individual but flexible and multidimensional co-constructions of an individual's sense of self. Identities are concerned with meanings, and specific configurations of meanings can be implemented functionally as roles through the community's communicative practices (Riley, 2007).

Learners who are speakers of minority languages try to construct their identities in social context and gain independence through use of the dominant language (Anderson, 1999). In line with what has been stated, Norton's (1997) theory takes into account the associations between power, identity, and language learning. Identity is concerned with propensity for recognition, affiliation, security, and safety (West, 1992). The relations of individuals' empowerment and different social sites make the issue of identity a potential ability that can be strengthened through opportunities in social contexts (Ball \& Ellis, 2008). According to Block (2007), migration is often "one in which critical experiences, leading to the emergence of new subject positions, are likely to occur" (p. 109); therefore, identity is not constructed by the context but it is affected by it and the immigrants' first language.

\section{The Effect of L1 on Identity Construction}

It should be pointed out that $70 \%$ of new immigrants to Canada speak a mother tongue other than one of Canada's two official languages (PurcellGates \& Tierney, 2009). The use of the mother tongue, along with an official language, empowers and encourages ESL learners to create their own dual identities and to engage in interactive discourse with target communities.

As Vygotsky (1978) noted, "the acquisition of language can provide a paradigm for the entire problem of the relation between learning and devel- 
opment ... [because] language arises initially as a means of communication between [a person] and the people in his [or her] environment" (p. 89). This process of scaffolding and interaction enables ESL speakers to be aware of each other's L1 and cultural understanding. However, this awareness of L1 power could have contradictory effects on the target society underlying the L1 culture, and it is capable of transforming the perspectives of the target society in an opposite direction.

If interaction occurs through drawing on the L1 with peers in daily activities, ESL learners provide themselves and their ethnocultural communities, including their peers, with further resilience and empowerment, which can affect the social positioning and culture of the second language society, as indicated by Wagner's (2004) "understanding of learning as empowerment of social participation" (p. 614). According to Roberts and Rosenwald (2001) and Wigglesworth (2010), learners have multiple identities that interact with second language learning. This idea comes to prominence in the idea that speakers of the majority language have a strong sense of identification that can lead to wider language involvement and language vitality in any given community (Giles \& Johnson, 1987).

Therefore, construction of identity is concerned with the social context in which language learning could establish a preferred social identity that may yield occasions for individuals to learn different language skills through immersion programs or direct practices.

\section{The Relation of Language, Identity, and Culture}

Knowledge construction regarding language learning relies upon the interaction of speakers of a minority language with their peers and the speakers of majority languages. This social interaction is also proposed by Vygotsky's (1978) notion of the Zone of Proximal Development (ZPD). When ESL learners are subjected to second language acquisition after puberty, both their construction of identity and their academic attainment are culturally and linguistically influenced by the target language community.

Constant exposure to the dominant language fosters resilience in communication and optimal language development. In fact, building identity as a result of bilingualism in minority communities turns the mother tongue into a marginal activity in the development and planning of school subject content, which focuses mostly on the majority language and tends to be "naively assimilatory" or "culturally neutral" (Reid \& Reich, 1992). This marginalization is observed extensively among speakers of minority languages in many of the larger cities in both Canada and the United States. Although this marginalization of L1 acquisition does not reflect structural changes in educational provision, the L1 may express categories of thoughts and affect the attitudes and beliefs of the target community (Kramsch, 2008). 
ESL learners consider their native language a type of additive bilingualism that differs from the dominant language in the target community, both socially and culturally. As stated by von Humboldt (1836/1988):

There resides in every language a characteristic world-view ... By the same act whereby [man] spins language out of himself, he spins himself into it, and every language draws about the people that possess it a circle whence it is possible to exit only by stepping over at once into the circle of another one. (p. 60)

Wolf (2006) argued that

language is the very foundation upon which the concept of "self" is based: in and through language, we present ourselves as subjects. Subjectivity is the speaker's ability to present himself as subject distinct from "the other" as object but always the other's potential subject to whom "I" says "you" and who says "you" to "I." (p.17)

Therefore, language (i.e., the L1) could play a critical role in the context of social empowerment in the second language because learners draw upon language skills in their first language as a self-empowering tool. This tool can gradually affect the sociocultural aspects of the target community in communication and in the achievement of particular social positioning in the target community.

The possibility that language could affect both people's attitudes and beliefs enables us to argue that the first language of minority speakers might reflect social and cultural changes in the context of bilingualism and multilingualism in three ways: (a) the discursive level considers that using language in a particular manner influences thinking, (b) the semiotic level emphasizes the way that any symbolic system alters thinking in certain ways, and (c) the linguistic level illustrates that a specific language may affect thoughts with respect to particular morpho-syntactic configurations of meaning.

In light of the symbiotic system that could transform ways of thinking, Lucy and Wertsch (1987) stated that "it is language which guides thought, although not to a higher level of development but to a culturally specific interpretation of experience" (p. 82). Parallel to this, speakers of minority languages may draw upon some dimensions of their L1, including thoughts and cultures of their native community. Therefore, their L1 accounts for the interaction of language, attitude, and social/cultural actions in communicative practice in everyday life.

Based on Kramsch's (2008) assertion that "language as communicative practice is tied to a person's position in time, space, social and historical relations, and his/her social and emotional identity" (p. 249), the feelings, beliefs, and social identities of individuals are constructed and affected by the actions and behaviours that stem from existence of the L1. 


\section{Gaining Insight into Empowerment by Language}

This article makes an effort to reach a more thorough and systematic understanding of the effects of the L1 on socially dual identities and "how language learners position themselves and are positioned by others depending on where they are, who they are with, and what they are doing" (Norton, 2000, p. 2). We emphasize a poststructuralist framework in which language is regarded as unstable and identities are multiple, contradictory, and subject to transformation across various settings and interactions. What arises as a problem here is the conflict between the culture of speakers of a minority language and that of speakers of a majority language. This problem may stem from differences in thinking or in the identity of people due to their L1 and may result in constraints that ESL immigrants encounter along the way.

In the case of monolingual speakers of a majority language in their own mainstream settings, the balance between socialism and culturalism enables them to achieve social positioning, as well as academic success. In contrast, bilingual speakers of a minority language face challenges concerning language and cultural manifestations in their behaviour in society.

Furthermore, the issue of empowerment is also related to the inevitable relation of language/identity (Norton, 2000):

Power does not operate only at the macro level of powerful institutions such as the legal system, the education system, and the social welfare system, but also at the micro level of everyday social encounters between people with differential access to symbolic (e.g., language, education, and friendship) and material (e.g., capital goods, real estate, and money) resources-encounters which are inevitably produced within language. (p. 7)

Pavlenko and Norton (2007) also explained that the relations of power can foster or restrict the range of identities that language learners can negotiate in their classrooms. Lave and Wenger (1991) state that "learning and a sense of identity are inseparable; they are aspects of the same phenomenon" (p. 115).

Since the L2 is not a carrier of their culture and identity, learners' attitudes and thoughts in their L1 can gradually affect the target culture, which, in many instances, may contribute to a community in which bilingualism and different identities cause cultural conflicts, communicative deficiency, and lack of social positioning and economic advancement in the target society. Moreover, this could jeopardize the sociocultural aspects of the target language.

\section{The Importance of Learner Autonomy}

Underlying all of these perspectives is the view that language learning is related to identity and culture, specifically the L1 through which learners could position themselves within the target society, using their own cultures 
and perspectives to transform sociocultural aspects of the target community as they see fit. One of the main factors that give the speakers of minority languages the means to use the cultural and social aspects of their L1 in target communities is the autonomy that Canadian policies provide as equity and human rights to ESL learners; they can preserve their own L1 along with their native cultures while learning either English or French as a second language. This autonomy is called liberatory autonomy and highlights learning to liberate as presented by Kumaravadivelu (2003): “While academic autonomy enables learners to be strategic practitioners in order to realize their learning potential, liberatory autonomy empowers them to be critical thinkers in order to realize their human potential" (p. 141).

Following the notion of liberatory autonomy, we can come to a new perspective regarding whether ESL learners influence the target community with the identity and culture related to their L1 society, or whether the sociopolitical or sociocultural aspects of the target society could be altered and shaped through the perspectives they bring to the new setting. It would be of interest to see the relationship, if any, between identity, as well as the L1 culture, and learning a foreign language.

New policies should take into account the concept of liberatory autonomy, which gives ESL immigrants or refugees the means to draw on their identities and L1 cultures and to participate in mainstream structures of political and economic power, enabling them not only to be critical thinkers but also to make a critical choice in their language of communication. Their positions, accompanied by their use of L1 and construction of dual identities, can be regarded as a threat to the powerful position of English speakers in the target setting.

\section{Conclusion}

The proposed methods of ESL/EFL language programs, which give the opportunity of acquiring languages in addition to the L1, not only in Canada but also all over the world, have the potential to impede or to accelerate future changes, which may erode or improve the existing status of immigrants or refugees in target societies with regard to their sense of detachment from or involvement in those societies. Language could be enumerated as one of the indices of such feelings, which is not capable of bringing about such powerful changes in identity and culture of target community by itself, but its use, along with cultural traditions and identity-related concepts to the L1, could be more promising. The main purpose of such language programs is the dissemination of ideas that seek to diminish the cultural and linguistic traces of non-English cultures; all these may be accommodated and emphasized in language programs.

Awareness of such consequences may enable governments to use these capacities for a better society. The benefits of language instruction and its 
effects are not limited to governing systems but extend to the immigrants and newcomers who utilize this tool for empowerment in their interaction and try to gain the same opportunities for social benefits as native speakers in their target setting. The necessary condition for such intended goals is the development of agreed standards and norms to enhance opportunities for newcomers.

\section{The Authors}

Fereshteh Tadayon is Lecturer in English Language Teaching at Kerman Higher Education Institute, Iran. Her research interests focus on qualitative assessment as well as language learning explored from language socialization and identity perspectives.

Ali Khodi is a second-year Ph.D. candidate majoring in applied linguistics at the University of Tehran, Kish International Campus, Iran. His main research interests include language testing and assessment, discourse analysis, and second language acquisition.

\section{References}

Allwright, D., \& Hanks, J. (2009). The developing language learner: An introduction to exploratory practice. London, UK: Palgrave Macmillan.

Anderson, M. (1999). Children in-between: Constructing identities in the bicultural family. Journal of the Royal Anthropological Institute, 5(1), 13-26. https://doi.org/10.2307/2660960

Ashworth, M. (2000). Effective teachers, effective schools: Second-language teaching in Australia, Canada, England and the United States. Toronto, ON: Pippin.

Ball, A. F., \& Ellis, P. A. (2008). Identity and the writing of culturally and linguistically diverse students. In C. Bazerman (Ed.), Handbook of research on writing (pp. 499-514). Mahwah, NJ: Lawrence Erlbaum.

Bassler, T. (1990). English language programms for refugees in St. John's, Newfoundland. TESL Canada Journal, 8(1), 101-113. https://doi.org/10.18806/tesl.v8i1.582

Block, D. (2007). The rise of identity in SLA research, post Firth and Wagner (1997). Modern Language Journal, 91(s1), 863-876. https://doi.org/10.1111/j.1540-4781.2007.00674.x

Giles, H., \& Johnson, P. (1987) Ethnolinguistic identity theory: A social psychological approach to language maintenance. International Journal of the Sociology of Language, 1987(68), 69-99. Amsterdam, Netherlands: Mouton de Gruyter. https://doi.org/10.1515/ijsl.1987.68.69

Kramsch, C. (2008). Language, thought, and culture. In A. Davies \& C. Elder (Eds.), Handbook of applied linguistics (pp. 235-261). Oxford, UK: Blackwell.

Kumaravadivelu, B. (2003). A postmethod perspective on English language teaching. World Englishes, 22(4), 539-550. https://doi.org/10.1111/j.1467-971X.2003.00317.x

Lave, J., \& Wenger, E. (1991). Situated learning: Legitimate peripheral participation. Cambridge, UK: Cambridge University Press. https://doi.org/10.1017/СBO9780511815355

Lucy, J. \& Wertsch, J. (1987). Vygotsky and Whorf: A comparative analysis. In M. Hickmann (Ed.), Social and functional approaches to language and thought (pp. 67-86). New York, NY: Academic Press.

Magsino, R. (1995). Multiculturalism in schools: Is multicultural education possible and justifiable? In L. W. Roberts \& R. A. Clifton (Eds.), Crosscurrents: Contemporary Canadian educational issues (pp. 253-270). Scarborough, ON: Nelson.

Norton, B. (1997). Language, identity, and the ownership of English. TESOL Quarterly, 31(3), 409-429. https://doi.org/10.2307/3587831

Norton, B. (2000). Identity and language learning: Gender, ethnicity, and educational change. London, UK: Longman. 
Pavlenko, A., \& Norton, B. (2007). Imagined communities, identity, and English language learning. In J. Cummins \& C. Davison (Eds.), International handbook of English language teaching (pp. 669-680). New York, NY: Springer. https://doi.org/10.1007/978-0-387-46301-8_43

Purcell-Gates, V., \& Tierney, R. (2009). Public policy brief: Increasing literacy levels of Canadian students. Retrieved from http://cpls.educ.ubc.ca/content/pdfs/LiteracyPolicyBrief.pdf

Reid, E., \& Reich, H. H. (1992). Breaking the boundaries: Migrant workers' children in the EC. Clevedon, UK: Multilingual Matters.

Riley, P. (2007). Language, culture and identity: An ethnolinguistic perspective. London, UK: Continuum.

Roberts, J. S., \& Rosenwald, G. C. (2001). Ever upward and no turning back: Social mobility and identity formation among first-generation college students. In D. P. McAdams, R. Josselson, \& A. Lieblich (Eds.), Turns in the road: Narrative studies of lives in transition (pp. 91-119). Washington, DC: American Psychological Association.

Von Humboldt, W. (1988). On language: The diversity of human language structure and its influence on the mental development of mankind (Trans. P. Heath). Cambridge, UK: Cambridge University Press. (Original work published 1836)

Vygotsky, L. (1978). Interaction between learning and development. Readings on the Development of Children, 23(3), 34-41.

Wagner, J. (2004). The classroom and beyond. Modern Language Journal, 88(4), 612-616.

West, C. (1992). A matter of life and death. Columbia University Academic Commons. http://hdl. handle.net/10022/AC:P:19152

Wigglesworth, A. (2010). Becoming citizens: Civil society activism and social change in Timor Leste (Doctoral dissertation, Victoria University, Melbourne, Australia). http://vuir.vu.edu.au/id/ eprint $/ 15530$

Wolf, A. J. (2006). Subjectivity in a second language: Conveying the expression of self (Vol. 8). Bern, Switzerland: Peter Lang. 